\title{
Chemiluminescence and Chemotaxis Assay of Canine Granulocytes: A Methodological Study
}

\author{
By Gunilla Trowald-Wigh and Kerstin Thorén-Tolling \\ Department of Medicine and Surgery, Veterinary Faculty, \\ Swedish University of Agricultural Sciences, Uppsala, Sweden.
}

\begin{abstract}
Trowald-Wigh. G. and K. Thorén-Tolling: Chemiluminescence and chemotaxis assay of canine granulocytes: A methodological study. Acta vet. scand. 1990, 31, 79-86. - Chemiluminescence (CL) of isolated granulocytes and of whole blood from dogs was evaluated. Chemiluminescence of whole blood samples created an undesired quenching effect by the red blood cells which makes the assay difficult to apply in pathological cases with low formation of oxygen metabolites. This problem was avoided when chemiluminescence was determined, using isolated granulocytes. A cell concentration of $5 \times 10^{9} / 1$ was needed to create optimal conditions. The Boyden chamber technique was used for study of random migration and chemotaxis. Casein $(0.1 \%)$, zymosan activated serum with and without $\varepsilon$-amino$\mathrm{n}$-caproic-acid and homologous serum were effective chemoattractants for canine granulocytes, while FMLP (formyl-methionyl-leucyl-phenylalanin) did not attract canine granulocytes.
\end{abstract}

neutrophil; whole blood chemiluminescence; temperature; cell concentration; chemotaxis; migration; zymosan activated serum; homologous serum; FMLP.

\section{Introduction}

Neutrophil granulocytes play an important role in the defense of the body against invading microorganisms. Neutrophils possess several different functions in this elimination process; e.g. to aid in recognition, chemotaxis, phagocytosis, intracellular killing by enzymes released by degranulation, formation of $\mathrm{H}_{2} \mathrm{O}_{2}$ and superoxide anion and finally digestion. Most information on granulocyte function has been derived from studies in other species than the dog. Consequently, relatively little is known on this particular topic in the dog although some studies relating to granulocyte function in this species are available. Among these are found a study by Chusid et al. (1975) who reported on defective neutrophil function in canine cyclic neutropenia, Renshaw et al.
(1977) who found a reduced intracellular bactericidal function in a dog with recurrent infections, and Bowles et al. (1979) who described an impaired chemotaxis in foxhounds with the Pelger-Hüet anomaly.

The aim of the present study was to apply and evaluate 2 previously used methods to study the function of granulocytes in the canine species. One of the methods, investigated here, concerns the intracellular killing capacity of granulocytes. Stimulation of phagocytosis of granulocytes results in degranulation and production of $\mathrm{H}_{2} \mathrm{O}_{2}$ and free oxygen radicals, a process which can be measured by chemiluminescence (CL) assay (Babior 1978). The other method investigated, involves the study of the migratory capacity (chemotaxis) of canine granulocytes. This can be evaluated by the in vitro 
Boyden-chamber technique which is based on determining the migratory capacity of granulocytes in a micropore filter system (Wilkinson \& Allen 1978).

\section{Materials and methods}

Experimental animals

Blood from 52 healthy dogs, 34 females and 18 males, age $1-11$ years (mean age 5.5 years) was used for studies on granulocytic chemiluminescence and chemotaxis. Four breeds were represented; German shepherd $(n=14)$, Labrador Retriever $(n=18)$, Boxer $(n=10)$ and Beagle $(n=10)$.

\section{Blood samples}

$10 \mathrm{ml}$ blood samples collected from the cephalic vein into heparinized tubes, (Vacutainer system Becton Dickinson, Meyland, France) for isolation of granulocytes and 5 $\mathrm{ml}$ blood was collected in EDTA tubes, (Vacutainer system Becton Dickinson) for determination of hemoglobin $(\mathrm{Hb})$, red blood cells $(\mathrm{RBC})$, white blood cells $(\mathrm{WB} / \mathrm{BC})$ and differential leucocyte count.

\section{Isolation of granulocytes}

$10 \mathrm{ml}$ blood was divided in 2 plastic tubes and carefully mixed with an equal volume of dextran solution; Dextran (T-500, Pharmacia Fine Chemicals, Uppsala, Sweden) (20 $\mathrm{g} / \mathrm{l})$ was diluted in physiological saline $(9 \mathrm{~g}$ $\mathrm{NaCl} / \mathrm{l})$. The erythrocytes were allowed to sediment for $30 \mathrm{~min}$ at room temperature. The supernatant was collected and centrifuged $(150 \times \mathrm{g})$ for $5 \mathrm{~min}$. The pellet containing the granulocytes was suspended in 1 $\mathrm{ml} \mathrm{NaCl}(9 \mathrm{~g} / \mathrm{l})$, and the suspensions were transferred to the same tube and centrifuged as previously described. The supernatant was removed and the cells were suspended in $2 \mathrm{ml} \mathrm{NaCl}(9 \mathrm{~g} / \mathrm{l})$. The remaining erythrocytes were hemolyzed with hypotonic saline for $30 \mathrm{sec}$. After another wash, the final cell suspension was diluted in Geys buffer $(\mathrm{NaCl}$ $136.9 \mathrm{mM}, \mathrm{KCl} 5.02 \mathrm{mM}, \mathrm{Na}_{2} \mathrm{HPO}_{4} 0.84$ $\mathrm{mM}, \mathrm{KH}_{2} \mathrm{PO}_{4} \quad 0.18 \mathrm{mM}, \mathrm{NaHCO}_{3} 2.98$ $\mathrm{mM}$, glucose $11.1 \mathrm{mM}, \mathrm{CaCl} 2.48 \mathrm{mM}$, $\mathrm{MgCl}_{2} 1.04 \mathrm{mM}$ ). Finally the granulocytes were diluted to a concentration of $5 \times 10^{9}$ cells $/ 1$. The final cell suspension contained $75 \%$ neutrophil granulocytes. Basophilic granulocytes, eosinophiles and mononuclear cells constituted the remaining $25 \%$. In the chemotaxis study using FMLP (Sigma, St. Louis, MD, USA) as a chemoattractant, albumin $(2 \mathrm{~g} / \mathrm{l})$ was added to the buffer.

\section{Zymosan opsonization}

Zymosan (Sigma) was dissolved in tris- $\mathrm{NaCl}$ buffer $(0.01 \mathrm{M}$ tris (hydroxymethyl)-amino methane, $0.15 \mathrm{~m} \mathrm{NaCl} / 1, \mathrm{pH} 7.4)$ and incubated for $10 \mathrm{~min}$ in $37^{\circ} \mathrm{C}$. Thereafter pooled dog serum to a final concentration of $20 \%$ was added. This mixture was incubated for $30 \mathrm{~min}$ in $37^{\circ} \mathrm{C}$ and thereafter centrifuged at $400 \times \mathrm{g}$ for $5 \mathrm{~min}$. The supernatant was removed and the pellet was diluted in tris$\mathrm{NaCl}$ buffer to yield a final concentration of $4 \mathrm{~g} / \mathrm{l}$.

\section{Luminol}

Luminol (Sigma) was diluted to a concentration of $1 \mathrm{~g} / \mathrm{l}$ and $0.025 \mathrm{~g} / \mathrm{l}$ in tris- $\mathrm{NaCl}$ buffer.

\section{Chemiluminescence of isolated granulocytes} Hundred $\mu \mathrm{l}$ of the isolated granulocytes $(5 \times$ $10^{9}$ cells/l) were mixed with $100 \mu \mathrm{l}$ opsonized zymosan particles. This mixture was instantly placed in the luminometer and 100 $\mu$ l of luminol $(25 \mathrm{mg} / \mathrm{l})$, was immediately added. Chemiluminescence was registered until the peak value was passed. During the course of this study, 2 different luminometers were used; one instrument which registered luminescence in millivolt $(\mathrm{mV})(\mathrm{Lu}-$ minometer, LKB, Stockholm, Sweden) and 
another instrument (Lumac, Kabi, Stockholm, Sweden) which registered luminescence in relative light units (RLU).

\section{Chemiluminescence of granulocytes in whole blood}

Fifty $\mu \mathrm{l}$ blood was diluted in $400 \mu$ l Gey's buffer and incubated at $37^{\circ} \mathrm{C}$ for $5 \mathrm{~min}$. Assuming a WBC content of $1 \times 10^{10}$ cells/ 1 and $70 \%$ granulocytes, $50 \mu$ l blood contains $3.5 \times 20^{5}$ cells. Hundred $\mu \mathrm{l}$ opsonized zymosan particles $(4.0 \mathrm{mg} / \mathrm{ml})$ were added and the mixture was incubated for $5 \mathrm{~min}$. The test tube was placed in position for measurement and $100 \mu \mathrm{l}$ Luminol $(1.0 \mathrm{~g} / \mathrm{l})$ was immediately added and CL was measured.

\section{Migration of isolated granulocytes}

In vitro migration of granulocytes was estimated by a leading front technique using a Boyden chamber system (Wilkinson 1974). Sawn off $1 \mathrm{ml}$ syringe barrels to which Millipore filters (3.0 $\mu \mathrm{m}$, SS Millipore Molsheim, France) were glued, (R-X glue Casco Nobel, Stockholm, Sweden) were used as containers for the granulocytes. The barrels were filled with $100 \mu \mathrm{l}$ of cell suspension $\left(5 \times 10^{9}\right.$ cells/l) in Gey's buffer. The barrels were placed in beakers filled with buffer or chemotactic substance to a level corresponding to the upper surface of the cell suspension (about $1 \mathrm{ml}$ ). The granulocytes were allowed to migrate for $60 \mathrm{~min}$ at $37^{\circ} \mathrm{C}$. The migration was stopped through immersion of the barrels with filters in absolute ethanol for at least $10 \mathrm{~min}$. This procedure also fixed the leucocytes and dissolved the glue. The filters were rinsed twice in deionized water and were stained with Mayers Hemalun solution (Kebo AB, Spånga, Sweden) for $5 \mathrm{~min}$. The solution was removed and the filters were washed 3 times in deionized water. Ethanol $(95 \%)$ was added and after $3 \mathrm{~min}$ the filters were put in an ethanol $(99 \%)$ bath for an- other $5 \mathrm{~min}$. After drying they were mounted on slides with Eukitt (Kebo) and given a coverslip. The filters were examined in a light microscope ( $\times 400$, plane lens). Migration was assayed according to the leadingfront method (Zigmond \& Hirsch 1973).

Samples were always run in duplicate and each filter was examined three times. Each value presented, represents the mean of these six estimations.

Random migration was defined as the migration of granulocytes through the filter with Gey's buffer only, below the filter. Chemotaxis was defined as the directed locomotion of granulocytes versus a gradient of chemotactic substances.

\section{Chemotactic substances}

Casein solution, $1 \mathrm{~g} / \mathrm{l}(\mathrm{n}=23)$ : Casein (Casein nach Hammersten, Merck, Darmstadt, West Germany) was dissolved in 0.01 $\mathrm{M} \mathrm{NaOH}$ and diluted in a modified Gey's buffer $\left(\mathrm{CaCl}_{2} 1.24 \mathrm{mM}, \mathrm{NgCl}_{2} \mathrm{mM}\right.$, for the rest as above).

Complement activated serum with and without $\varepsilon$-amino-n-caproic-acid ( $\mathrm{n}=$ 11): Pooled fresh dog serum form 4 dogs was incubated with zymosan particles (Sigma) $1.5 \mathrm{mg} / \mathrm{ml} \mathrm{serum} \mathrm{for} 20 \mathrm{~min}$ at $37^{\circ} \mathrm{C}$ and thereafter centrifuged for $5 \mathrm{~min}(375 \times \mathrm{g})$. In the $\varepsilon$-amini-n-caproic-acid-assay, the $\varepsilon$-caproic-acid was added to serum in a concentration of $65.6 \mathrm{mg} / \mathrm{ml}$. The supernatant was collected and stored frozen at $-70^{\circ} \mathrm{C}$.

Homologous serum $(n=21)$ (Serum and granulocytes from the same dog): Fresh dog serum was diluted in Gey's buffer to a concentration of $10 \%$.

FMLP ( $=11$ ): Formyl-methionyl-leucylphenylalanin (FMLP) (Sigma, St Louis, MD USA) was diluted to $10^{-6}$ and $10^{-9}$ in Tris$\mathrm{NaCl}$ buffer. 


\section{Statistics}

Statistical analysis was performed with Students t-test on Paired observations on SAS (Statistical Analysis System). The error of estimation was calculated as the coefficient of variation $(\mathrm{CV})$ from duplicate samples according to the formula $s=\sqrt{\frac{\sum d 2}{2 n}}$.

\section{Results}

Chemiluminescence in whole blood versus isolated granulocytes

Blood specimen from 11 clinically healthy dogs were used to determine the chemiluminescence of whole blood and of isolated granulocytes. Isolated granulocytes demonstrated significantly $(\mathrm{p}<0.001)$ higher chemiluminescence $(158845 \pm 88749$ RLU $($ mean $\pm \mathrm{SD}))$ than the amount of whole

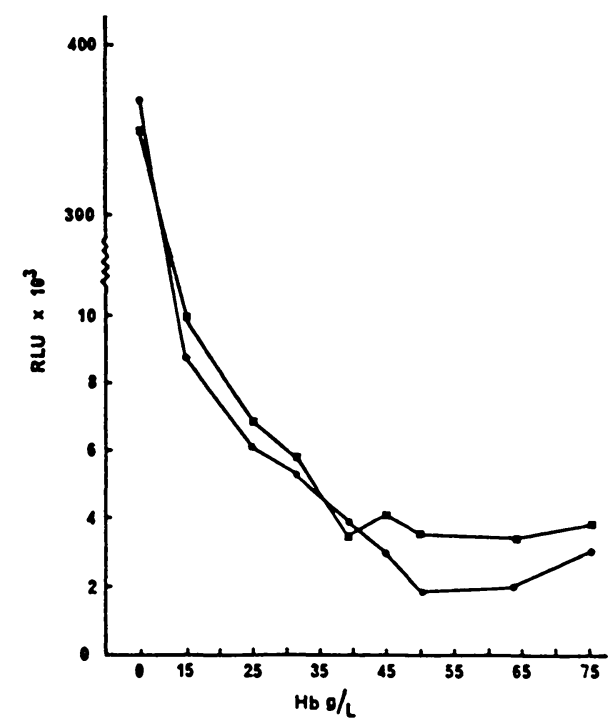

Figure 1. The quenching effect of erythrocytes on the chemiluminescence (CL) activity of isolated granulocytes $\left(8 \times 10^{9}\right.$ cells/l) from two dogs (๑ - . $\bullet$ and - . - $\square$ ). The CL activity is expressed in relative light units (RLU) when no erythrocytes are present $(\mathrm{Hb}=0 \mathrm{~g} / \mathrm{l})$ and then for increasing amounts of erythrocytes added (expressed as $\mathrm{g} / \mathrm{l}$ of $\mathrm{Hb}$ ). blood that contained approximately the same number of granylocytes $(2253 \pm 875$ RLU (mean $\pm \mathrm{SD})$ ). The correlation between chemiluminescence of whole blood and of isolated granulocytes is $r=0.334$. The possible quenching effect of erythrocytes on chemiluminescence of whole blood was investigated by adding pooled washed erythrocytes in increasing concentrations to a constant number of granulocytes before the determination of chemiluminescence. The erythrocyte concentration in each granulocyte suspension was estimated by means of measurement of the concentration of hemoglobin. The inhibition of granulocyte chemiluminescence by erythrocytes is demonstrated in Fig. 1.

Influence of cell concentration on determination of chemiluminescence

Chemiluminescence was performed on 5 samples with different cell concentrations $\left(1.25,2.5,5.0,7.5\right.$ and $\left.10.0 \times 10^{9} / 1\right)$ from each of 2 dogs. The granulocytes were stored concentrated in Gey's buffer after isolation and were diluted just prior to the experiment. In order to minimize the effect of storage, the chemiluminescence registration was stopped as soon as maximum activity had been registered, i.e. when the values turned to be lower.

A cell concentration of at least $5 \times 10^{9} / 1$, resulted in a chemiluminescence reading of sufficient sensitivity (Fig. 2).

\section{Influence of temperature on chemilumin- escence determination of isolated granulocytes}

Chemiluminescence was measured at $37^{\circ}$ and $39^{\circ} \mathrm{C}$, respectively on isolated granulocytes from the same dog $(n=12)$. The interval between the observations was less than $10 \mathrm{~min}$. 


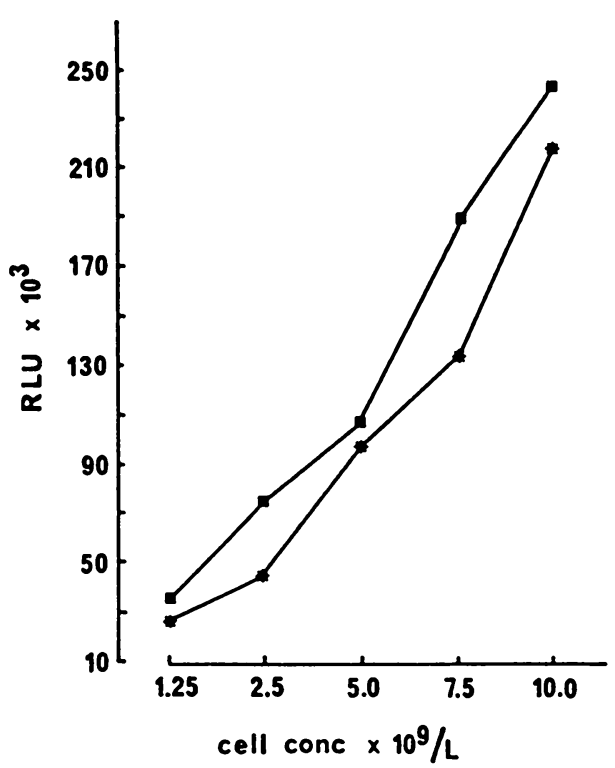

Figure 2. The influence of five different concentrations of isolated granulocytes on the chemiluminescence recordings in two dogs ( - . - $\square$ and * - . *). The chemiluminescence is expressed in relative light units (RLU).

An increase in the temperature from $37^{\circ}$ to $39^{\circ} \mathrm{C}$ did not increase the chemiluminescence of the granulocytes during phagocytosis of zymosan particles (mean \pm SD for $37^{\circ} \mathrm{C}$ : $\left.107 \pm 31.5,39^{\circ} \mathrm{C}: 83 \pm 37.4, \mathrm{p}<0.05\right)$.

Effect of storage time on chemiluminescence of isolated granulocytes

Chemiluminescence determinations were performed immediately after cell separation and at every $60 \mathrm{~min}$ for $5 \mathrm{~h}$. Granulocytes from 8 dogs were stored concentrated in Gey's buffer and diluted to $5 \times 10^{9} / 1$ just prior to registration. Chemiluminescence response was registered in RLU. After $3 \mathrm{~h}$ of storage of isolated granulocytes at room temperature, chemiluminescence response decreased ( $p<0.05$ ) (Fig. 3) when compared to freshly harvested cells.

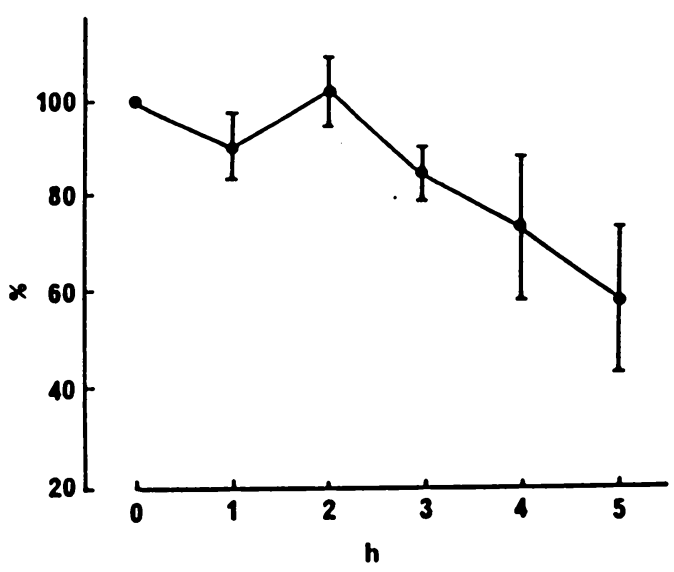

Figure 3. The effect of time on storage om chemiluminescence recordings of isolated granulocytes $\left(5 \times 10^{9}\right.$ cells $\left./ \mathrm{l}\right)$ from 8 dogs. Chemiluminescence was performed immediately after isolation of granulocytes (time 0 ) and then at hourly intervals for $5 \mathrm{~h}$. Chemiluminescence is registered in relative light units (RLU). The value obtained for each dog at time 0 was arbitrarily designated as $100 \%$. Values are given as means \pm SD.

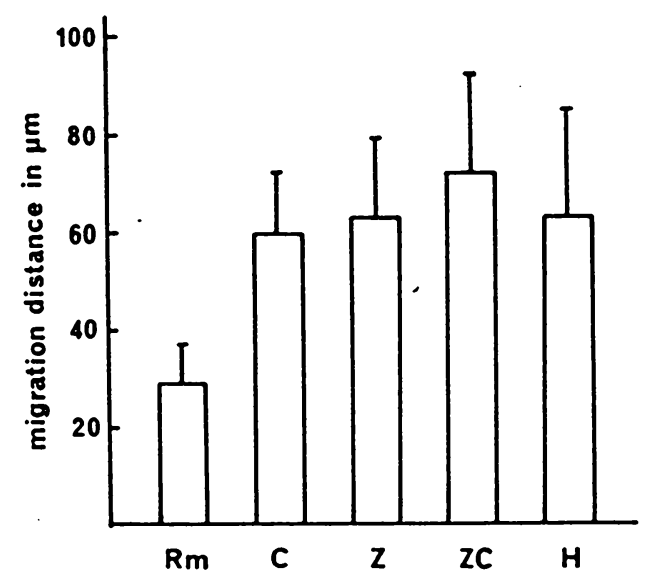

Figure 4. The influence of different chemotactic substances on the migration distance, expressed in $\mu \mathrm{m} / 60 \mathrm{~min}$ compared to random migration with Gey's buffer below the filter $\left(5 \times 10^{9}\right.$ pure granulocytes $/ \mathrm{l})$. $\mathrm{Rm}=$ random migration, $\mathrm{n}=30 ; \mathrm{C}=\mathrm{ca}$ sein, $\mathrm{n}=23 ; \mathrm{Z}=$ zymosan opsonized serum, $\mathrm{n}=$ 11; $\mathrm{ZC}=$ zymosan opsonized serum with caproic acid, $n=23 ; H=$ homologous serum, $n=21$. 


\section{Random migration and chemotaxis}

Random migration and chemotaxis of granulocytes from blood samples of 30 healthy dogs were examined (Fig. 4). For the study of chemotaxis the following different chemoattractants were investigated: casein $(\mathrm{n}=$ $23)$, zymosan activated serum $(n=11)$ and serum activated with zymosan and caproic acid $(n=23)$, homologous serum $(n=21)$ and finally FMLP $(n=11)$.

The migration distance of granulocytes in response to the chemoattractants tested was higher ( $p<0.001$ ) when compared to random migration. There was no significant difference in migration distance between the different chemotactic substances except between casein and zymosan/caproic acid ( $p$ $<0.05$ ).

FMLP did not act as a chemotactic substance for isolated canine granulocytes. Its chemotactic property was indistinguishable from that of random migration with albumin (mean \pm SD for random migration: 42 \pm 5.0, FMLP $10^{-6}: 44 \pm 4.1$, FMLP $10^{-9}$ : $43 \pm 4.5, \mathrm{p}<0.05)$.

\section{Sensitivity of the methods}

Chemiluminescence was determined in duplicate on isolated cells from 12 dogs. After cell isolation, the cell suspension was diluted to a concentration of $5 \times 10^{9}$ cells/l. The peak value of $C L$ was registered. The procedure was immediately repeated on the next sample from the same cell suspension. The methodological error, calculated from the difference between duplicate analysis of the same samples was $11.31 \%(\mathrm{CV})$. In the chemotaxis assessment the error was calculated from the difference between the means of the readings of the 2 filters $(\mathrm{CV})$. The error calculated from the difference between determinations of the same samples was $11.5 \%$ for random migration, for casein $9.4 \%$, for homologous serum $11.6 \%$, for zymosan acti- vated serum $5.5 \%$ and for zymosan activated serum with caproic acid $9.1 \%$.

\section{Discussion}

The purpose of this work was to develop functioning methods for $\mathrm{CL}$ and chemotaxis measurement on healthy dogs in order to be able to evaluate results obtained from dogs with recurrent infections.

As mentioned previously, the present method for isolating granulocytes yields about $75 \%$ neutrophils. In the methods used we cannot exclude the involvement of eosinophils, and among the mononuclear cells, the monocytes manifest active chemotaxis and kill microbes also by myeloperoxidase activity. Considering the low number of these cells this additive effect is small.

When measuring the maximal production of oxygen metabolites by $\mathrm{CL}$ assay on whole blood the values have to be corrected for the amount of erythrocytes present in the blood since they interfere with the registration by imposing a quenching effect even at very low erythrocyte concentrations (corresponding to hemoglobin values of $15-20 \mathrm{~g} / \mathrm{l})$. This is probably the reason why the registrered values for the whole blood samples are much lower than the corresponding values for isolated granulocytes. Furthermore, the blood plasma itself as compared to the buffer system used for isolated granulocytes may exert a dampening effect on chemiluminescence. Due to the low recordings of oxygen metabolites for the $\mathrm{CL}$ assay on whole blood, this method seems to be less useful as a test system for screening purposes in individual dogs. Chemiluminescence on isolated granulocytes gave higher recordings and thus leaves a larger range for differentiation of pathological cases. It was decided to use chemiluminescence of isolated granulocytes, although being more cumbersome, as the preferred method. 
A cell concentration of $5 \times 10^{9} / 1$ was selected for measuring chemiluminescence in the dog. The same amount of cells has also been used by other investigators, both in dogs (Angle \& Klesius 1983) and other animal species (Zinkl \& Brown 1982, Thorén-Tolling subm. for publ.). However, in man a granulocyte concentration of approximately $10^{9}$ cells/1 is optimal for this type of assay (Håkansson \& Venge 1980, 1985, Dahlgren et al. 1982, Hindocka \& Wovel 1985). This phenomenon is not fully understood but it seems obvious that a certain concentration of granulocytic cells is needed for an optimal phagocytic activity and that this concentration may be species dependent.

Staehr Johansen et al. (1983) found that an elevation of the temperature from $37^{\circ}$ to $40^{\circ} \mathrm{C}$ increases chemiluminescence response in human granulocytes after stimulation with zymosan while temperature above $40^{\circ} \mathrm{C}$ decreases chemiluminescence. Angle \& Klesius (1983) found, that canine granulocytes show a peak at $37^{\circ} \mathrm{C}$. We could not confirm this, but owing to practical reasons, mainly with regard to the instrumentation, the CL as well as the chemotaxis assays were standardized to $37^{\circ} \mathrm{C}$.

The decrease in CL response after $3 \mathrm{~h}$ storage probably reflects an impaired viability of the granulocytes. It is thus important to standardize the time interval from cell isolation until chemiluminescence recording.

FMLP did not attract granulocytes in our system. this probably indicates that canine granulocytes lack adequate receptors for this substance. This phenomenon has been reported earlier in dogs (Stickle et al. 1985, Redl et al. 1983) as well as in another domestic species (Chenoweth et al. 1980, Snyderman \& Pike 1980, Zinkl \& Brown 1982, Thorén-Tolling, subm. for publ.). In man, however, the FMLP peptide seem to have a high specificity for granulocyte receptors and the chemoattractant effect on granulocytes is well documented (Dahlgren et al. 1982, van Dyke et al. 1984). Differences in receptor mechanism as well as in structure or distribution of cell membrane lipids between species have also been discussed as possible reasons for the species dependent chemoattractant capacity of FMLP (Wilkinson \& Allen 1978, Chenoweth et al. 1980). The methodological variation of the chemotactic response was lowest with casein as chemoattractant and also random migration had a comparatively low variation. Taken together all chemoattractants studied with the exception of FMLP may be suitable for the study of chemotaxis of isolated dog granulocytes.

A conclusion from this study is that even if whole blood CL is a rapid and simple method it is not suitable for canine granulocytes in the clinical situation. Furthermore, all the chemoattractants tested except for FMLP are suitable for canine granulocytes.

\section{Acknowledgements}

The authors would like to express their sincere thanks to associate professor Lena Håkansson for very valuable advice and help and to laboratory assistant Ulla Nestor for excellent laboratory assistance. This study was supported by grants from Jordbrukets Försäkringsbolag, Stockholm, Thure F. and Karin Forsbergs Foundation Found and the Swedish Kennelclubs Found for Research.

\section{Reference}

Angle UJ, Klesius PH: Luminol-dependent chemiluminescence analysis of variables for the phagocytic response by canine granulocytes. Clin. Immunol. and Immunopathol. 1983, 4, 333-334.

Babior BM: Oxygen dependent microbial killing by phagocytosis. New Engl. med. J. 1978, 298, 659-668.

Bowles CA, Alsaker RD, Wolfe TL: Study of the Pelger-Hüet anomaly in foxhounds. Am. J. Pathol. 1979, 96, 237-247.

Chenoweth DE, Lane TA, Rowe JG, Hugki TE: Quantitative comparison of neurophil chemotaxis in four animal species. Clin. Immunol. and Immunopath. 1980, 15, 525-535. 
Chusid MJ, Bujak JS, Dale DC: Defective polymorphonuclear leukocyte metabolism and function in Canine Cyclic Neutropenia. Blood 1975, 46, 921-930.

Dahlgren C, Magnusson KE, Stendahl $O$, Sundquist $T$ : Modulation of polymorphonuclear leukocyte chemiluminescent response to the chemoattractant f-met-leu-phe. Int. Archs. Allergy Appl. Immunity 1982, 68, 79-83.

Hindocka $P$, Wovel $C B$ : Histamine release from leukocytes by IgG4 subclass in the sera of allergic children. Allergy 1985, 40, 523-528.

Håkansson L, Venge P: The influence of serum on random migration and chemotaxis of polymorphonuclear leukocytes. Methodological evaluation using sera from infection prone patients. Scand. J. Immunol. 1980, 11, 271-282.

Håkansson L, Venge $P$ : The chemotactic response of granulocytes to the low molecular weight chemoattractant FMLP, C5f and LTB4 is dependent on chemokinetic factors. J. Leukocyte Biology 1985, 38, 521-530.

Redl H, Flynn PJ, Lamche H, Schiesser A, Schlag $G$, Hammerschmidt DE: Aggregation, chemotaxis and chemiluminescence of canine granulocytes. Inflammation 1983, 7, 1, 67-80.

Renshaw HW, Davis WC, Renshaw SJ: Canine granulocytopathy syndrome: defective bacterial capacity of neutrophils from a dog with recurrent infections. Clin. immunol. Immunopath. 1977, 8, 385-395.

Snyderman $R$, Pike $M C$ : $\mathrm{N}$-formyl-methionyl receptors on equine leukocytes initiate secretion but not chemotaxis. Science 1980, 209, 493495.

Staehr Johansen K, Berger EM, Repine JE: Effect of temperature on polymorphonuclear leucocyte function. Acta path. Microbiol. Immunol. Scand. Sect. C. 1983, 93, 355-359.

Stickle JE, Kwan DK-H, Smith CW: Neutrophil function in the dog: shape change and response to a synthetic tripeptide. Am. J. vet. Res. 1985, 46, 225-228.

Thorén-Tolling $K$ : Chemiluminescence and chemotaxis assay of porcine polymorphonuclear cells. (Submitted for publication).

van Dyke $K$, Castranova V, van Dyke $C$, Kirten Michaux IMA, Mollison $K W$, Carter $G W$ : Granulocyte response to oxidized FMLP. Evidence for partial inactivation of FMLP. Inflammation, 1984, 10, 87-99.
Wilkinson PC: Chemotaxis and inflammation. Churchill Livingstone, London 1974.

Wilkinson PC, Allen RB: Assay for measuring leucocyte locomotion: an overview. In: JI Gallin and PG Quie (Editors): Leucocyte chemotaxis. Raven Press, New York 1978, pp. 1-24. Zigmond SH, Hirsch JG: Leukocyte locomotion and chemotaxis. New methods for evaluation and demonstration of a cell-derived chemotactic factor. J. exp. Med. 1973, 137, 387-410.

Zinkl. JG, Brown PD: Chemotaxis of horse polymorphonuclear leukocytes to $\mathrm{N}$-formyl-L-methionyl-L-leucyl-L-phenylalanine. Am. J. vet. Res. 1982, 4, 613-616.

\section{Sammanfattning}

Chemiluminescence och kemotaxis: en metodologisk studie avseende hundens granulocyter.

Detta arbete omfattar en evaluering av en metod at mäta granulocyters förmåga till avdödning, $\mathrm{s} k$ chemiluminescence $(\mathrm{CL})$ samt en utvärdering av olika kemotaktiska substanser i en Boyden kammarmetod för mätning av granulocyters kemotaxis hos hund.

Med avsikt att utveckla en snabbare netod för mätning av CL, användes helblod som jämfördes med isolerade celler från samma individ. Responsen blev dock så dämpad att det ej skulle vara möjligt bedöma en eventuell funktionsstörning med för låg chemiluminescence $\mathrm{i}$ den kliniska situationen. Olika cellantal testades och $5 \times 10^{9}$ celler/1 bedömdes som en lämplig koncentration då den gav tillräckligt stort utslag för att en underfunktion skulle kunna diagnostiseras. Temperaturens inverkan på responsen undersöktes genom att mäta $\mathrm{CL}$ vid $37^{\circ}$ och $39^{\circ} \mathrm{C}$ men det förelåg ej någon signifikant skillnad mellan mätningarna. Lagring av celler längre än 3 timmar ger signifikant lägre chemiluminescence. Det är således viktigt att man standardiserar tiden mellan cellisolering och mätning av CL.

Olika kemotaktiska substanser (casein, zymosanaktiverat serum med och utan $\varepsilon$-kapronsyra, homologt serum och formyl-methionyl-leucocylphenylalanin, (FMLP)) användes för att stimulera granulocyternas kemotaxis och jämfördes med ej stimulerad migration där cellerna fick vandra mot buffert. Samtliga kemotaktiska agens utom FMLP attraherade hundgranulocyter i detta system och kan följaktligen användas i en klinisk situation för att diagnosticera patologiska tillstånd.

\section{(Accepted April 20, 1989).}

Reprints may be requested from: Gunilla Trowald-Wigh, Department of Medicine and Surgery,

Veterinary Faculty, Swedish University of Agricultural Sciences, P. O. Box 7037,

S-750 07 Uppsala, Sweden. 